\title{
Triage of General Oncological Surgery During COVID-19 Pandemic
}

\author{
COVID-19 Pandemisi SIrasında Genel Onkolojik Cerrahide Triaj
}

\author{
Ali Cihat Yildirim, Mehmet Fatih Ekici, Sezgin Zeren, Faik Yaylak, Mustafa Cem Algin \\ General Surgery Department, Kutahya Health Sciences University, Faculty of Medicine, Kutahya, Turkey
}

\begin{abstract}
A world wide pandemic of COVID 19 has been affected by the global health system of the majority of the world. The significant burden of the pandemic results in severe damage to several steps of health supply. Although significant health authorities and surgical societies gave the rapid response to this world wide outbreak, major concerns emerge for emergency and oncological cases which could be life-threatening on this sophisticated chaotic crisis environment. Local precautions should be considered on this outbreak when every country and geographical region may manage its resources with severe limitations. In this review, we try to collect recommendations about the triage of general surgical cancer care which are emphasized by the Turkish surgical community and world oncological societies up to date.
\end{abstract}

Key words: triage; COVID 19; oncological surgery; general surgery

\section{ÖZET}

Dünya çapında COVID 19 adında bir salgın global sağlık sistemini etkilemektedir. Sağlık zinciri bir çok așamada pandeminin yol açtığı ciddi bir yük tașımaktadır. Dünya sağlık otoriteleri ve cerrahi dernekler bu pandemiye hızla cevap verip kılavuzlar hazırlasalar da, kaotik kriz ortamında yașamı tehdit eden acil ve onkolojik cerrahi vakaların yönetimiyle ilgili ciddi bir endișe söz konusudur. Her ülkenin elindeki tıbbi kaynakları ciddi kısıtlamalarla kullandığı bu ortamda yerel önlemlerin alınması önem kazanmıștır. Bu derlemede genel cerrahi kanser vakalarının yönetiminde Türk ve dünya onkolojik cerrahi dernekleri tarafından ortaya konan kılavuz önerileri ortaya konulmuștur.

Anahtar kelimeler: triaj; COVID 19; onkolojik cerrahi; genel cerrahi

\section{Introduction}

Since January 2020, a world-wide pandemic of COVID 19 was announced by WHO (World Health Organization) and which primarily results in pneumonia with a range of symptoms and disease course. This virus outbreak has been changed the whole human-related life issues starting from health issues. First Chinese physicians and scientist try to describe the disease characteristics, and many guidelines and recommendations have been updated for diagnostic and treatment processes ${ }^{1,2}$. Disease-specific recommendations have emerged since the epidemiological data was revealed that this virus-led infectious disease would most likely affect the immuno-compromised patients ${ }^{3}$. In early studies published in China revealed cancer patients have a twofold increased risk of COVID-19 infection. Nevertheless, the fatality rate of COVID-19 patients with pre-existing malignancy is higher than patients without any comorbid conditions. Disease severity is also increased in cancer patients with COVID-19 infection. So the management of cancer therapy needs careful triage of case and disease-specific considerations.

Surgical and cancer societies from different countries have been published in several general and cancer-type specific recommendations so far. There are many aspects and issues which oncological and surgical care have to be evaluated more carefully in this pandemic era when COVID-19 precautions have been added additional burden and responsibility to both physicians and patients. In this narrative review, we try to assess both general oncological principles and cancer-type specific recommendations during COVID 19 Pandemia.

IIetișim/Contact: Ali Cihat Yildirim, Kutahya Health Sciences University, Faculty of Medicine, General Surgery Department, Kutahya, Turkey • Tel:05056466695 • E-mail: dralicihatyildirim@gmail.com • Geliș/Received:15.05.2020 • Kabul/Accepted:28.08.2020

ORCID: Ali Cihat Yuldirum, 0000-0001-5379-2804 • Mehmet Fatih Ekici, 0000-0002-1247-1139 • Sezgin Zeren, 0000-0002-9342-1706 • Faik Yaylak, 0000-0002-1216-0429 • Mustafa Cem Algin, 0000-0003-2152-878X 


\section{Review of Available Recommendations}

\section{A. General Considerations}

\section{1) Issues related to country and human resources}

There are many challenges to encounter during the pandemic. Primary of them is the optimal use of health staff across the country. Some oncology teams might work as common care givers during the pandemic. So careful planning should be made to organize of cancer physician is necessary. Another critical issue is to ensure a suitable health environment which results in minimal interruption of cancer therapies, especially for patients whose disease are in a curative stage.

Finding available resources of medical therapeutics might be problematic during this outbreak. This could lead to a significant negative impact on cancer care. For some cancers, there are a few options of drugs for clinical preferences and drug shortages may be lifethreatening. In such a case, it is meaningful to use all available resources to cases which are really presented as an emergency ${ }^{3}$.

\section{2) Issues related to local/hospital resources}

According to ACS (AmericanCollege of Surgeons) Elective Case Triage Guidelines for Surgical Care there are 3 Phases of hospitals regarding the feasibility of resources including ICU beds, number of available ventilators etc. during COVID-19 pandemic. Surgical cases should be evaluated according to these phases of the local hospital ${ }^{4}$.

Phase 0: No COVID-19 patients, hospital operating as normal

Phase 1: Semi-Urgent Setting (Preparation Phase). Few COVID 19 Patients, hospital resources not exhausted, there are enough ICU ventilator capacity, COVID case trajectory not in the rapid escalation phase

Phase 2: Urgent Setting. Many COVID 19 Patients, ICU beds and ventilator capacity limited, OR supplies limited or COVID case trajectory within the hospital in rapidly escalating phase

Phase 3: All hospital resources devoted to COVID 19 patients, no ventilator, ICU beds, OR supplies exhausted.

\section{3) Issues related to patient factors}

The previous medical history and age are essential factors to be assessed before analyzing the relative risk of hospitalization which can lead to increased COVID 19 transmission, so a decision which weighs the benefit more than the risk like neoadjuvant chemotherapy rather than operation.

Patients should be evaluated for ICU need or perioperative potential morbidity risk requiring long hospitalization before any surgical attempt. If the hospital resources are not enough to even for COVID-19 patients, elective oncological cases could be deferred.

The patient's informed consent for surgery is more essential during the pandemic. The COVID-19 specific health risks should be added the informed consent, and overall risks should be clearly discussed with the patient and thefamily 5 .

\section{4) Issues related to cancer-specific factors}

ACS released "Guidance for Triage of non-Emergent Surgical Procedures" and evaluated cancer patients with "ESAS (Elective surgery acuity scale) Tiersystem" (Table 1). This system evaluates both malignant and non-malignant cases according to the urgency of the operation. Although there are not rigid approaches for non-malignant elective surgeries during the pandemic, patients with cancer who have possible curative surgery on preoperative evaluation should undergo surgery if the delay of surgical therapy more than three months leads adverse oncological outcomes to the patient ${ }^{3}$.

In modern cancer care, the oncological therapy of the patient had been evaluated by a multidisciplinary team, including the surgeon, medical oncologist, radiation oncologist, pathologist, nuclear physician. In this pandemic era, multidisciplinary meetings should be made on online fashion without any need of specific time, and all cancer cases should be evaluated on its own biologic nature ${ }^{4-6}$.

Considering the ESAS tierscale, many cancer patients might be considered as Tier 2 a or Tier $2 b$. After a careful evaluation by a multidisciplinary team surgeon should consider alternative measures in case of high-risk features related to patient, environment and resources. Cases considered as Tier $3 \mathrm{a}$ or Tier $3 \mathrm{~b}$ should undergo available procedures to solve the urgent condition.

\section{B. Cancer Type-Specific Considerations}

Most gastrointestinal cancer surgeries are not elective. Urgent cases should be done with precautions against COVID-19 transmission risk, which are nicely detailed in previous studies ${ }^{1,2}$. If there sources of the hospital are not adequate to perform and manage possible 
perioperative complications, the surgery should be delayed, or the patient should be referred to a centre with eligible resources ${ }^{7}$.

\section{1) Gastric and oesophagal cancer}

After evaluating hospital COVID 19 phase response when both surgery and non-surgical alternatives could be possible options for Phase 1, but for Phase 2-3 surgery should be delayed until the pandemic rates diminish and resources are eligible. On Table 2 possible treatment options of gastric cancer were detailed according to cancer stage $e^{5,7}$.

\section{2) Hepato-pancreato-biliary (HPB) cancers}

These are cancers which are usually not considered as elective operations and have aggressive biologic behaviour. After a rapid evaluation of the hospital phase response, every single case should be managed by a multidisciplinary team where surgery remains the mainstay of curative treatment. The other "next beter options" could be practised by this team. For liver cancers chemotherapy, ablativetechniques (percutaneous, MIS, open with thermal/non-thermal), embolic therapies (radioembolization, TACE), radiosurgery, biliary stents may

Table 1. Elective surgery acuity scale (ESAS) Tier protocole

\begin{tabular}{|c|c|c|c|c|}
\hline Tiers/Description & Definition & Locations & Examples & Action \\
\hline Tier1a & $\begin{array}{l}\text { Low acuity surgery/healthy patient } \\
\text { Outpatient surgery } \\
\text { Not life-threatening illness }\end{array}$ & $\begin{array}{l}\text { HOPD } \\
\text { ASC }\end{array}$ & $\begin{array}{l}\text { EGD } \\
\text { Colonoscopy }\end{array}$ & $\begin{array}{l}\text { Postpone surgery or perform } \\
\text { ASC }\end{array}$ \\
\hline Tier $1 b$ & Low acuity surgery/unhealthy patient & $\begin{array}{l}\text { HOPD } \\
\text { ASC } \\
\text { Hospital with low/no } \\
\quad \text { COVID-19 census }\end{array}$ & & $\begin{array}{l}\text { Postpone surgery or perform } \\
\text { ASC }\end{array}$ \\
\hline Tier 2a & $\begin{array}{l}\text { Intermediate acuity surgery/healthy patient } \\
\text { Not life-threatening but potential for future } \\
\text { morbidity and mortality } \\
\text { Requires in-hospital stay }\end{array}$ & $\begin{array}{l}\text { HOPD } \\
\text { ASC } \\
\text { Hospitalwith low/no } \\
\quad \text { COVID-19 census }\end{array}$ & $\begin{array}{l}\text { Low risk of cancer } \\
\text { Non-urgent orthopaedic, urologic } \\
\quad \text { operations }\end{array}$ & $\begin{array}{l}\text { Postpone surgery if possible } \\
\text { consider ASC }\end{array}$ \\
\hline Tier $2 b$ & Intermediate acuity surgery/unhealthy patient & $\begin{array}{l}\text { HOPD } \\
\text { ASC } \\
\text { Hospital with low/no } \\
\quad \text { COVID-19 census }\end{array}$ & & $\begin{array}{l}\text { Postpone surgery if possible } \\
\text { consider ASC }\end{array}$ \\
\hline Tier3a & High acuity surgery/healthy patient & Hospital & $\begin{array}{l}\text { Most cancers } \\
\text { Highly symptomatic patients }\end{array}$ & Do not postpone \\
\hline Tier $3 b$ & High acuity surgery/unhealthy patient & Hospital & & Do not postpone \\
\hline
\end{tabular}

HOPD: Hospital Outpatient Department, ASC: Ambulatory Surgery Center

Table 2. Gastric cancer treatment during COVID-19 pandemic

\begin{tabular}{|c|c|}
\hline Clinical Situation & Treatment \\
\hline T1a & $\begin{array}{l}\text { Phase 1.ESD/EMR when eligible resources } \\
\text { Phase 2-3: Defer the procedure and weekly reassessment }\end{array}$ \\
\hline T1b and T2 without clinically positive lymph node & $\begin{array}{l}\text { Surgical resection; however, a 4-6 week time to operation is reasonable until best optimal } \\
\text { resources enabled. }\end{array}$ \\
\hline T2 with positive lymph node or T3 or higher Grade Cancers & $\begin{array}{l}\text { Neoadjuvant chemotherapy is recommended } \\
\text { *Laparoscopy to rule out occult metastases before chemotherapy could be skipped when } \\
\text { aerosolization concerns due to low hospital resources }\end{array}$ \\
\hline Patients after neoadjuvant treatment & $\begin{array}{l}\text { After neoadjuvant therapy 3-6 weeks to surgery but on a multidisciplinary fashion an } \\
\text { additional 1-2 cycles of chemotherapy can be added during the pandemic crisis } \\
\text { Cancers non-responsive to therapy should be considered for surgery }\end{array}$ \\
\hline Complicated Cases & $\begin{array}{l}\text { Endoscopic procedures risky for aerosol transmission and only should be considered to allow } \\
\text { nutrition and control bleeding under full PPE. } \\
\text { For proximal tumours with uncomplete obstruction chemoradiotherapy may obviate the need } \\
\text { for a stent and diminish bleeding } \\
\text { For complete obstruction, surgery could be warranted }\end{array}$ \\
\hline
\end{tabular}


be optimal choices with/without surgery. For pancreato-biliary cancers, chemotherapy, radiationtherapy, targeted immunotherapies may be optimal "next beter options" besides resection (MIS, open) and transplantation (biliarycancers). Table 3 shows treatment options according to the hospital phase response $\mathrm{e}^{7,8}$.

\section{3) Colorectal cancers}

"Turkish Society of Colon and Rectal Cancer Surgery" published Colo-Rectal Cancer Management Guideline during COVID-19 Pandemic. Colorectal cancer therapy has many options to perform.

Tailored colorectal cancer treatment was proposed regarding patients risks, clinical presentation, tumour characteristics, surgical risk factors and current situation of the healthcare system ${ }^{9}$. These recommendations could be integrated with ACS Hospital Phase Response system and ESAS Tier based system. Treatment options were shown in Table $4^{10,11}$.

Table 3. Treatment for HPB cancers during pandemic

\begin{tabular}{llll}
\hline Cancer Site & Clinic & Phase 1 & Phase 2 \\
\hline Liver & HCC & Ablation, resection, transplantation & TACE, ablation, careful lobservation \\
& Early-stage & & \\
& Laterstages & TACE, Medical therapy, supportive care. & \\
& Colorectal Mets &
\end{tabular}

\begin{tabular}{|c|c|c|c|}
\hline \multirow{3}{*}{ Biliary } & & Resection for Tier 2a, chemotherapy for Tier $2 \mathrm{~b}$ or greater & Chemotherapy \\
\hline & $\begin{array}{l}\text { Intrahepatic } \\
\text { Cholangiocarcinoma }\end{array}$ & Resection for Tier 2a, chemotherapy for Tier $2 b$ or greater & Chemotherapy, embolictherapy \\
\hline & Hilar cholangiocarcinoma & $\begin{array}{l}\text { Stenting } \\
\text { Resection and transplantation if indicated }\end{array}$ & $\begin{array}{l}\text { Stenting } \\
\text { Chemotherapy, chemoradiation and/or } \\
\text { transfer to an eligible unit }\end{array}$ \\
\hline \multirow[t]{2}{*}{ Pancreatic } & Resectable & Resection or chemotherapy & Neoadjuvant chemotherapy \\
\hline & Borderline & Neoadjuvantchemotherapy & Neoadjuvant chemotherapy \\
\hline Extra-hepaticbiliary & $\begin{array}{l}\text { Pancreatic IPMN, cysts, } \\
\text { low-moderate grade } \\
\text { neuroendocrinetumours }\end{array}$ & $\begin{array}{l}\text { All observation/delay in the surgical management } \\
\text { For neuroendocrine metastatic/progressive tumours } \\
\text { targeted therapy }\end{array}$ & \\
\hline
\end{tabular}

Table 4. Treatment options for colorectal cancer patients during COVID 19 pandemic

\begin{tabular}{|c|c|c|c|}
\hline Clinical Condition & Phase 1 & Phase 2 & Phase 3 \\
\hline $\begin{array}{l}\text { Large suspicious polyps, hereditary syndromes, } \\
\text { dysplasia/carcinoma in situ in biopsy } \\
\text { specimens, incomplete margins on } \\
\text { polypectomy }\end{array}$ & \multicolumn{3}{|c|}{$\begin{array}{l}\text { All off these entities would be evaluated as Tier } 1 \text { or } 2 a \text { and specific surgeries might be delayed for } \\
\text { COVID-19 Phase } 1-3 \text { Hospitals until pandemic subsides. }\end{array}$} \\
\hline Early cancer found on resected polyp: Tier 2 & Defer surgery or Resection & Defer Surgery & \\
\hline $\begin{array}{l}\text { Asymptomatic Cancer } \\
\text { T1-2 N0 (Tier 2) }\end{array}$ & Resect & Resect or defer surgery & Defer Surgery \\
\hline $\begin{array}{l}\text { Asymptomatic Cancer } \\
\text { Colon T3-4, N0 andTx N+ (Tier 2) }\end{array}$ & Resect & Resect or defer surgery & $\begin{array}{l}\text { Chemotherapy or transfer to an eligible } \\
\text { reference unit in Phase } 0-2\end{array}$ \\
\hline Rectal T3-4, N0 and Tx N+ (Tier 2) & $\begin{array}{l}\text { Induction chemotherapy or c } \\
\text { Defer surgery up to } 12-16 \mathrm{v}\end{array}$ & $\begin{array}{l}\text { רoradiation or radiation, Extended } \\
\text { ks after completion of radiation }\end{array}$ & chemotherapy if the tumor response well \\
\hline $\begin{array}{l}\text { Symptomatic Cancers (Tier } 3 \text { ) defined as } \\
\text { bleeding requiring transfusion, obstructing } \\
\text { or near-obstructing, impending perforation. }\end{array}$ & Resection & $\begin{array}{l}\text { Resection } \\
\text { Stoma or endoscopic stenting }\end{array}$ & $\begin{array}{l}\text { Stoma or endoscopic stenting } \\
\text { Transfer to an eligible reference unit in } \\
\text { Phase } 0-2\end{array}$ \\
\hline
\end{tabular}


Alternative treatment options specific for colorectal cancer patients may include neoadjuvant chemotherapy for locally advanced resectable colon cancer; total neoadjuvant therapy for locally advanced resectable rectal cancer; and extended delay of surgery to $12-16$ weeks after neoadjuvant radiotherapy. For bleeding cancer cases, radiotherapy and embolization are other options. Cases of near-obstructing tumor are eligible for endoscopic stenting and chemo-radiotherapy where possible. For resectable oligo-metastatic disease, therapy could be go on with systemic therapy and ablative/embolic approaches could be alternative options ${ }^{10,11}$. Primary anastomosis in high risk patients (ultra-low anastomoses, diabetics, preoperative radiotherapy, elderly must be avoided ${ }^{6}$.

Another ongoing debate for minimal invasive surgery (MIS) vs. open surgery was still on track. When viral spread via carbondioxide aerosolization during MIS approaches entails a concerning risk, the choice of operation type must be evaluated in the context of patient benefit, available resources like smoke filters against viral transmission and protective equipment for personnel ${ }^{10,11}$.

\section{4) Breast cancers}

Unlike the gastrointestinal cancers, selected breast cancer surgery could be deferred. Oncological and hormonal therapy may have priority during this outbreak. General recommendations were shown in Table $5^{4,12}$. In some situations like proceeding surgery vs neoadjuvant chemotherapy which might lead the patient to an immuno-compromised state, a multidisciplinary based, individualized approach is needed according to local resources. Although the radiation oncology unit might be closed during the pandemic breast-conserving therapy should be encouraged when possible ${ }^{4}$. For all phases, autologous reconstructions should be deferred ${ }^{12}$.

Nevertheless, there are still a few emergencies for breast cases. Patients with progressive disease on systemic treatment, angiosarcoma and malignant phyllodes tumour should be considered as breast emergencies and not be deferred ${ }^{12}$.

\section{5) Endocrine cancers}

Most of the endocrine cancer operations can be delayed. Urgent surgery for endocrine cancers have interferred as surgery required within 4-8 weeks during

Table 5. Treatment options for breast cancer patients during COVID 19 pandemic

\begin{tabular}{|c|c|c|c|}
\hline Clinical Situation & Phase 1 & Phase 2 & Phase 3 \\
\hline $\begin{array}{l}\text { Cases to be done as soon } \\
\text { as eligible resources }\end{array}$ & $\begin{array}{l}\text { Patients after neoadjuvant treatment } \\
\text { Clinical stage T2 or N1 Estrogen(ER) / Progesterone(PR) / HER2 } \\
\quad \text { negative tumors } \\
\text { Triple-negative or HER2 positive tumours } \\
\text { Excision of malignant recurrence } \\
\text { Biopsies likely to be malignant }\end{array}$ & $\begin{array}{l}\text { Breast abscess requiring } \\
\quad \text { incision and drainage } \\
\text { Hematoma drainage } \\
\text { Revision for ischemic flap } \\
\quad \text { after mastectomy }\end{array}$ & $\begin{array}{l}\text { Breast abscess requiring } \\
\text { incision and drainage } \\
\text { Hematoma drainage } \\
\text { Revision for ischemic flap } \\
\quad \text { after mastectomy }\end{array}$ \\
\hline \multirow[t]{2}{*}{ Cases to be deferred } & $\begin{array}{l}\text { Excision of benign lesions } \\
\text { Biopsies likely to be benign } \\
\text { High risk lesions(Atypia, papillomas) } \\
\text { Prophylactic cancer/non-cancer surgeries } \\
\text { cTisNO lesions-ER positive and negative } \\
\text { Re-excision surgery } \\
\text { Tumours responding to neoadjuvant hormonal treatment } \\
\text { Clinical Stage T1NO ER/PR positive and Her2 negative tumours } \\
\quad \text { which might receive hormonal therapy }\end{array}$ & & \\
\hline & $\begin{array}{l}\text { Inflammatory and locally advanced cancers when patients should } \\
\text { receive neoadjuvant therapy }\end{array}$ & All breast operations & All breast operations \\
\hline \multirow[t]{2}{*}{$\begin{array}{l}\text { Alternative options } \\
\text { (When resources eligible) }\end{array}$} & $\begin{array}{l}\text { T1 NO ER/OR positive and Her2 negative tumours can receive } \\
\text { hormonal therapy* }\end{array}$ & & \\
\hline & $\begin{array}{l}\text { For triple-negative and Her2 positive tumours neoadjuvant therapy } \\
\text { Some of T2 N1 ER/PR positive and Her two negative tumours are } \\
\text { candidates for hormonal therapy* }\end{array}$ & $\begin{array}{l}\text { Neoadjuvant therapy for } \\
\quad \text { eligible patients } \\
\text { Observation }\end{array}$ & $\begin{array}{l}\text { Neoadjuvant therapy for } \\
\quad \text { eligible patients } \\
\text { Observation }\end{array}$ \\
\hline
\end{tabular}

*Some patients with early-stage ER-positivetumours do not have a response tochemotherapy well. Amongst them are patients with stage 1 or some stage 2 cancers, low-intermediate grade tumours, lobular carcinomas, low Oncotype DX scores(<25), luminal A cases. There is significant clinical evidence supporting primary endocrine therapy lasting 6-12 months before surgery. 
Table 6. Urgent endocrine surgery cases to be done during COVID 19 pandemic

\begin{tabular}{|c|c|}
\hline Cancer Type & Urgent Cases (Cases to be done within 4-8 weeks during the pandemic) \\
\hline Thyroid & $\begin{array}{l}\text { Life-threatening cases with local invasion (trachea, recurrent laryngeal nevre etc), aggressive biology (rapidly growing tumors, } \\
\text { recurrence, rapidly progressive local-regional disease } \\
\text { Symptomatic Graves Disease when medical treatment failure } \\
\text { Giant goitre which leads airway obstruction } \\
\text { Highly suspicious cases for anaplastic thyroid cancer and lymphoma requiring open biopsy }\end{array}$ \\
\hline Parathyroid & Cases of hyperparathyroidism with severe hypercalcemia unresponsive to medical treatment \\
\hline Adrenal & $\begin{array}{l}\text { Adrenocortical cancer or highly suspicious cancer } \\
\text { Cases of pheochromocytoma or paraganglioma which are unable to control with medical therapy } \\
\text { Cases of symptomatic Cushing's syndrome which are unable to control with medical therapy }\end{array}$ \\
\hline $\begin{array}{l}\text { Neuroendocrine Tumors } \\
\text { (NET's) }\end{array}$ & $\begin{array}{l}\text { Small bowel NETs which are symptomatic like obstruction, bleeding, ischemia } \\
\text { Functional and symptomatic NETs of the pancreas which are unable to control with medical therapy } \\
\text { Symptomatic non-functional NETs of the pancreas which are unable to control with somatostatin analogues }\end{array}$ \\
\hline Other & Endocrine surgeries in pregnant women should not be delayed for potential harm to mother or foetus when medical therapy fails. \\
\hline
\end{tabular}

pandemic were shown in Table $6^{13,14}$. The otherwise functional adrenal tumour which response to medical therapy well and asymptomatic non-functional adrenal adenomas can be delayed. Cytoreductive surgery should be considered after individualized decision led by the multidisciplinary team ${ }^{13}$.

\section{Conclusion}

ECCO (European Cancer Organization) has indicated that the health care providers should provide a COVID-19 test for all cancer patients who are receiving any kind of oncological therapy. Cancer patients who might have possible contact within 14 days and who have classic COVID-19 symptoms should be analyzed. A low-threshold to order a thorax CT could be feasible in case of discrepancy between clinical findings and the testing ${ }^{6}$.

Due to the increased risk of cancer patients to infections, their oncological therapy should be managed by outpatient fashion as soon as eligible. Hospitalizations should be devoted to new cancer patients and symptomatic patients primarily. Virtual visits by telephone should be encouraged. Classical visits should be performed by minimum required health staff, cancer surgeries should be underwent by minimum required surgical teams wearing full personel protective equipment described by societies. ERAS protocols might be enabled for all cancer patients and outpatient surgeries might be prioritized. MIS for cancer should be undertaken after evaluating possible risk and benefits regarding the hospital resources ${ }^{4,6,12,15}$.
The caregivers should minimalize cancer patients exposure to the healthcare facilities. In case of positive COVID 19 test of any cancer patient, infection treatment should be prioritized over oncological therapy except urgent surgical needs ${ }^{16,17}$. The therapy must be individualized to diminish perioperative risks. Diagnostic tools like endoscopic and interventional procedures should be tailored for suspected cases. Psychological aspects of cancer patients should be evaluated primarily when their concerns about treatment delay and isolation result in psychological and even physical fear ${ }^{6}$.

\section{References}

1. Karaca AS, Ozmen MM, Uçar AD, Yastı AÇ, Demirer S. General Surgery operating room practice in patients with COVID-19. Turkish Journal of Surgery. 2020; Volume 36, Issue 1 .

2. Kamer E, Çolak E. What to do when a patient infected With COVID-19 needs an operation:A Pre-surgery, Peri-surgery and Post-surgery Guide. Turk J Colorectal Dis 2020;30:1-8

3. Al-Shamsi HO, Alhazzani W, Alhuraijii A, Coomes EA, Chemaly R.F, Almuhanna $M$ et al. A practical approach to the management of cancer patients during the novel Coronavirus Disease 2019 (COVID-19) Pandemic: An International Collaborative Group. Oncologist. 2020 Apr 3. Doi:10.1634/ theoncologist.2020-0213. Online ahead of print.

4. COVID-19 Recommendations for management of elective surgical procedures. Released March 24, 2020. FACS Clinical Issues and Guidance. Available online at https://www.facs.org/ covid-19/clinical-guidance/elective-surgery 
5. SAGES recommendations regarding surgical management of gastric cancer patients during the response to the COVID-19 crisis. Published online at April 11,2020. Available online at: https://www.sages.org/sages-recommendations-surgicalmanagement-gastric-cancer-covid-19-crisis/

6. What should surgeons know in cases of oncological pathology in the context of COVID-19 pandemic (SARS COV-2)? Recommendations from surgeons-AEC-COVID 19 of the Spanish Association of Surgeon(AEC). Updated 04-0620 Available online at: https://www.aecirujanos.es/files/ noticias/158/documentos/RECOMMENDATIONS_ FROM_SURGEONS_AEC-COVID19.pdf

7. Resource for management options of GI and HPB Cancers during COVID-19. Society of Surgical Oncology. Published March 20, 2020. Available online at: https://www.surgonc. org/wp-content/uploads/2020/03/GI-and-HPB-Resourceduring-COVID-19-3.30.20.pdf

8. SAGES-AHPBA recommendations regarding surgical management of HPB cancer patients during the response to the COVID-19 crisis. Society of American Gastrointestinal and Endoscopic Surgeons. Published on April 11, 2020. Available online at: https://www.sages.org/sages-ahpbarecommendations-surgical-management-of-hpb-cancercovid-19/

9. Akyol C, Koç M.A, Utkan G, Yıldız F, Kuzu MA. The COVID-19 Pandemic and colorectal cancer:5W1H What should we do to whom, when, why, where and how? Turk J Colorectal Dis 2020;30:67-75. DOI:10.4274/tjcd. galenos.2020.2020.4.11

10. SAGES recommendations regarding surgical management of colorectal cancer patients during the response to the COVID-19 crisis. Published April 11, 2020. Available online at: https:// www.sages.org/recommendations-surgical-managementcolorectal-cancer-covid-19/
11. Resource for management options of Colorectal Cancer during COVID-19. Society of Surgical Oncology. Published:March 30, 2020 Available online at: https://www.surgonc.org/ wp-content/uploads/2020/03/Colorectal-Resource-duringCOVID-19-3.30.20.pdf

12. Resource for management options of breast cancer during COVID-19.Published March 30, 2020. Available online at: https://www.surgonc.org/wp-content/uploads/2020/03/ Breast-Resource-during-COVID-19-3.30.20.pdf

13. Resource for management options of endocrine/head and neck cancer during COVID-19. Published March 30, 2020. Available online at: https://www.surgonc.org/wp-content/ uploads/2020/03/Endocrine-Head-and-Neck-Resourceduring-COVID-19-3.30.20.pdf

14. Prioritisation of endocrine surgery during the COVID-19 pandemic. Newsletter Of European Society of Endocrine Surgeons(ESES). Available online at: https://www. endokrincerrahisi.org/files/file/NL-2020-Prioritisation of_Endocrine_Surgery_during_the_Covid-19_pandemicESES_2020.pdf

15. Updated intercollegiate general surgery guidance on COVID-19. RoyalCollege of Surgeons. Updated:7 April,2020. Available online at: https://www.rcseng.ac.uk/coronavirus/ joint-guidance-for-surgeons-v2/

16. Advice for surgical oncologists on cancer service provision. Statement on COVID-19. The European Society of Surgical Oncology. Available online at: https://www.essoweb.org/news/ esso-statement-covid-19/

17. Burki TK. Cancer guidelines during the COVID-19 pandemic. The Lancet Oncology. Published:April 02, 2020 DOI:https:// doi.org/10.1016/S1470-2045(20)30217-5 